\title{
CHEMICAL AND FUNCTIONAL PROPERTIES OF PROTEIN ISOLATE FROM COWPEA (Vigna Unguiculata)
}

\author{
Yuli Witono", Choirul Anam*, Herlina", Agustia Dwi Pamujiati ${ }^{*}$ \\ \# Department of Agricultural Product Technology, Faculty of Agricultural Technology, University of Jember \\ Jalan Kalimantan 37, Jember, 68121, Indonesia \\ E-mail:ylwitono@yahoo.com
}

*Department of Agrotechnology, Faculty of Agricultural, Darul Ulum Islam University, Jalam Airlangga 3, 62253, Lamongan, Indonesia E-mail: choirul.anam19@yahoo.com

\begin{abstract}
Cowpea (Vigna unguiculata) is potentially used as food ingredient since it has high protein content around $25 \%$. This study was focused on the observation of the chemical and functional properties of cowpea protein isolate (CPI) compared to the chemical and functional properties of soy protein isolate (SPI) commercial with three repetitions in each parameter, then the data were analyzed descriptively. The results showed that CPI has the chemical properties of the moisture content, ash content, and carbohydrate content, which value is smaller than the value of SPI respectively $7.97 \%, 1.75 \%, 1.21 \%$. CPI has protein and fat content which is higher, compared to SPI with consecutive values $88.06 \%$ and $1.05 \%$. CPI contains more $7 \mathrm{~S}$ globulin fraction compared with $11 S$ and inversely related to SPI. CPI has functional properties including maximum solubility at pH 8, smaller foam capacity and higher foam stability than the value of SPI successive $68 \mathrm{ml} / \mathrm{g}$ and $8 \%$, lower OHC and WHC than SPI at successive $84.89 \%$ and $136.61 \%$, lower emulsion capacity and higher emulsion stability than the value of SPI with consecutive $2.41 \mathrm{~m}^{2} / \mathrm{g}$ and $78.15 \mathrm{hours}$, lower than the gelation of SPI with a value of 4 gf. CPI has a major fraction of protein bands with molecular weight of $59.11 \mathrm{kDa}$ and $54.22 \mathrm{kDa}$, while the fraction of SPI has major protein bands with molecular weight of $50.66 \mathrm{kDa}$ and $57.02 \mathrm{kDa}$
\end{abstract}

Keywords - cowpea protein isolate, chemical and functional properties, 7S and 11S globulin.

\section{INTRODUCTION}

Cowpea (Vigna unguiculata) has been widely known in Indonesia. [1] state that Cowpea production has reached 1,3 million tons. Every 100 gram-Cowpea material has nutrient content of 22.9 grams of protein, 1.1 grams of fat, and 61.6 grams of carbohydrates. This highly nutritional value makes cowpea deserved to be considered as a source of vegetable protein food to meet nutritional needs [2].

Protein isolate is the result of food protein isolation using the method of isolation of specific protein to produce the product with high protein concentration and pure. Chemical and functional properties such as solubility, $7 \mathrm{~S}$ and $11 \mathrm{~S}$ globulins, water holding capacity (WHC), oil holding capacity (OHC), emulsion properties, foam properties, gelation properties of protein isolates can improve the quality and organoleptic properties of food products. When the food industry is growing, the need for protein isolates will also increase.

Protein isolates are generally made from soybeans which are mostly imported from abroad. 2010. [3] showed a fairly high value for imported raw materials of protein isolate was 1.192.173 tons. Though, Indonesia has the potential of local legumes protein source that can be used as raw material for the manufacture of protein isolates. The study of protein isolates from local materials has been developed but the results are less satisfactory. Mung bean protein isolates and fermented cowpea protein isolates only has protein content of $76.56 \%$ [4] and $82.59 \%$ [5]. Cowpea production is high enough to be used as an alternative raw material for making protein isolates. The technique of making cowpea protein isolates has been developed, but so far unknown chemical and functional properties of cowpea protein isolate as a scientific basis for further utilization for food ingredients.

\section{MATERIALS AND METHODS}

Materials

The basic material used for this research is cowpea derived from Malang, East Java and commercial soy protein isolate. Chemical materials used specification pro analysis Merck brands (Germany) covering $0.1 \mathrm{~N} \mathrm{NaOH}, 1 \mathrm{~N} \mathrm{HCl}$, 
$0.5 \mathrm{~N} \mathrm{HCl}, 70 \%$ acetone, $0.1 \mathrm{M}$ phosphate buffer $\mathrm{pH} 7$, $0.05 \mathrm{M}$ phosphate buffer $\mathrm{pH} 7$, SDS $0.1 \%$, Tris- $\mathrm{HCl}$ buffer $0.03 \mathrm{M} \mathrm{pH} \mathrm{8,} \mathrm{Lowry} \mathrm{reagent,} \mathrm{Follin,} \mathrm{Temed,} \mathrm{ammonium}$ persulfate $10 \%, 30 \%$ polyacrylamide stock, $50 \%$ methanol, CBB R-250 0.05\%, and glacial acetic acid $10 \%$.

\section{Preparation of Cowpea Protein Isolate}

The Preparation of CPI begins with cowpea weighing 100 grams and soaked in water for \pm 5 hours. Peeled epidermis and cuticle-free cowpea crushed using a blender and add distilled water ratio of 6:2 (water: materials). Thus, the obtained suspension was filtered in order to produce cowpea milk. Cowpea milk was added $0,1 \mathrm{~N} \mathrm{NaOH}$ in the ratio 5:1 (NaOH: suspension) and incubated at $55^{\circ} \mathrm{C}$ for 30 minutes. Then, the milk was separated by using a centrifuge at $2000 \mathrm{rpm}$ for 10 minutes. The supernatant was conditioned at $\mathrm{pH} 5$ by the addition of $1 \mathrm{~N} \mathrm{HCl}$ and separated by using a centrifuge again at $2000 \mathrm{rpm}$ for 10 minutes. While, the sediment is wet protein isolate purified using $70 \%$ acetone. After stirring with a stirrer was performed for 20 minutes and separation using a centrifuge at $2000 \mathrm{rpm}$ for 10 minutes. The precipitate was dried using a vacuum oven at a temperature of $50{ }^{\circ} \mathrm{C}$ for 8 hours. CPI dried crushed and sieved using a 80 mesh sieve. After that, the cow pea protein isolate analyzed the chemical and functional properties compared to the properties of commercial soy protein isolates (SPI).

\section{Chemical and Functional Properties Analysis}

Chemical properties measured were moisture content [6], ash content [6], fat content use soxhlet method [7], protein content use micro kjeldahl [7], carbohydrate content (By difference ), the ratio of $7 \mathrm{~S}$ and $11 \mathrm{~S}$ globulins [8] and the composition of protein isolate fractions [9]. Functional properties of protein solubility was observed at various $\mathrm{pH}$ [10, foam capacity and foam stability [10], oil holding capacity (OHC) [10], water holding capacity (WHC) [10], emulsion capacity and stability [11] and gelation [12].

\section{Data Analysis}

The data of chemical and functional properties of CPI were averaged over each parameter and analyzed descriptively. To interprete easily, the data were ploted in the table, histogram, or a picture.

\section{RESULT AND DISCUSSION}

\section{A. Chemical Properties of Cowpea Protein Isolate}

The data of CPI and SPI chemical properties can be seen in Table 1.

TABLE 1

CHEMICAL PROPETIES OF CPI AND SPI

\begin{tabular}{lcc}
\hline \multicolumn{1}{c}{ Parameters } & CPI $(\boldsymbol{\%})$ & SPI $(\boldsymbol{\%})$ \\
\hline Water & $7.93 \pm 0.33$ & $10.52 \pm 0.06$ \\
\hline Ash & $1.75 \pm 0.30$ & $1.94 \pm 0.23$ \\
\hline Fat & $1.05 \pm 0.16$ & $0.41 \pm 0.32$ \\
\hline Protein & $88.06 \pm 0.96$ & $85.77 \pm 0.32$ \\
\hline Carbohydrate & $1.21 \pm 0.96$ & $1.36 \pm 0.75$ \\
\hline
\end{tabular}

Table 1 shows that the CPI moisture content of $7.93 \pm 0.33 \%$ while the moisture content SPI of
$10.52 \pm 0.06 \%$. High levels of moisture SPI was influenced by storage. SPI is only stored in plastic without any silica gel that absorbs moisture surrounding air. In accordance with the Triyono [4], stated that the moisture content of the product depends on the packaging and storage time. Poor packaging could cause damage to the product and shelf life of the product would not be long. CPI moisture content in this study was not so different from isolates protein moisture content of green beans is equal to $7.39 \%$ [4].

CPI ash content is $1.75 \pm 0.30 \%$ while the ash content SPI is $1.94 \pm 0.23 \%$ (Table 1). CPI ash content values is lower than the SPI because the ash content of cowpea is also lower than that of soybean ash content of $1.97 \%$ and $2.14 \%$ [13]. CPI ash content in this study is lower than the ash content of jack bean protein isolate that is equal to $2.66 \%$ [14].

Table 1 shows that the CPI fat content is $1.05 \pm 0.16 \%$ while the SPI fat content is $0.41 \pm 0.32 \%$. High fat content in CPI allegedly due to fat solvents used in the manufacturing process of CPI is acetone what is not so maximum dissolves the fat so that the fat content of CPI is higher. Also according to Iskandar [15], SPI is made from fat-free soy flour to produce a protein isolate with a lower fat content.

CPI protein content is $88.06 \pm 0.96 \%$ and SPI protein content is $85.77 \pm 0.32 \%$ (Table 1). CPI has higher protein content than the SPI. CPI protein content of these results is far different from mung bean protein isolates and fermented cowpea protein isolates are equal to $76.56 \%$ [4] and $82.59 \%$ [5]. In the fermented cowpea protein isolates, proteins already hydrolyzed since the fermentation process in order the protein content decreased.

CPI carbohydrate content is $1.21 \pm 0.96 \%$ and SPI carbohydrate content is $1.36 \pm 0.75 \%$ (Table 1 ). CPI has lower carbohydrate content than the SPI. The results of this study also showed that the carbohydrate content of CPI is lower carbohydrate content than the jack bean protein isolate. Subagio [14] reported that the carbohydrate content of jack bean protein isolates is $21.48 \%$.

The ratio of $7 \mathrm{~S}$ and $11 \mathrm{~S}$ globulins contributes to the robustness and elasticity of the gel formed in food. The results of the analysis of $7 \mathrm{~S}$ and $11 \mathrm{~S}$ globulin ratio CPI and SPI can be seen in Table 2 below.

TABLE 2

RATIO OF 7S AND 11S GLOBULINS CPI AND SPI

\begin{tabular}{ccc}
\hline Sampel & \multicolumn{2}{c}{ Globulin levels sample type (\%) } \\
\cline { 2 - 3 } & 7S Globulin & 11S Globulin \\
\hline CPI & $0.03 \pm 0.03$ & $0.02 \pm 0.00$ \\
SPI & $0.05 \pm 0.01$ & $0.25 \pm 0.07$ \\
\hline
\end{tabular}

The table above shows that the $7 \mathrm{~S}$ globulin of CPI has more than $11 \mathrm{~S}$ globulin with the value of $0.03 \pm 0.03 \%$, while the SPI with more $11 \mathrm{~S}$ globulin than $7 \mathrm{~S}$ globulin is equal to $0.25 \pm 0.07 \%$. This is consistent with that expressed by Horax et al. [16], that cowpea protein has simplicity in the structure of this protein, which mostly constitutes of 7S sub unit.

The composition fraction of cowpea protein isolate and soy protein isolates were performed using gel electrophoresis as be seen in Figure 1 below. 


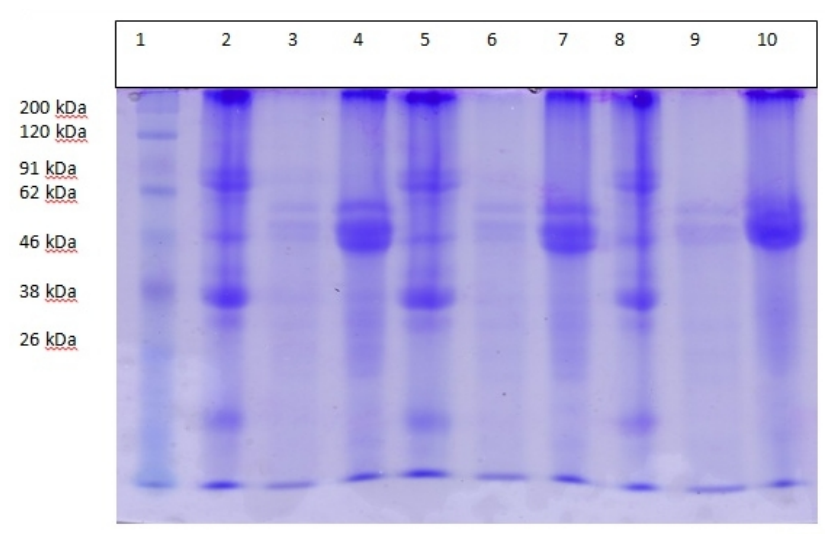

Fig 1. Results of SDS-PAGE electrophoresis (1: marker; 2, 5, 8: SPI; 3, 6, 9: CPI dry; 4, 7, 10: CPI wet)

Figure 1 shows that the SPI has 6 bands with molecular weight of protein fraction in a row is $79.23 ; 80.45 ; 60.57$; $52.03 ; 33.88$ and $22.43 \mathrm{kDa}$. Protein fraction with a molecular weight of 80.45 and $33.88 \mathrm{kDa}$ is the major protein fraction. CPI dried protein fraction has 5 bands with successive molecular weight of $65.67 ; 59.11 ; 54.22 ; 37.57$ and $32.11 \mathrm{kDa}$. Major protein fraction is the fraction of proteins with molecular weight of 59.11 and $54.22 \mathrm{kDa}$. Wet CPI has 8 bands of protein fractions by successive molecular weight of $65.53 ; 57.02 ; 50.66 ; 37.06 ; 31.56 ; 27.10 ; 24.94$ and $22.86 \mathrm{kDa}$. Protein fraction with a molecular weight of 50.66 and $57.02 \mathrm{kDa}$ is the major protein fraction. In accordance with research Horax et al. [16] which states that the cowpea protein has a molecular weight of major proteins ranged from 40 to $66.2 \mathrm{kDa}$.

\section{B. Functional Properties of Cowpea Protein Isolate}

The Functional properties analyzed include protein solubility at various $\mathrm{pH}$, foam capacity and foam stability, oil holding capacity (OHC), water holding capacity (WHC), emulsion capacity and emulsion stability, and gelation.

1) The Solubility of Proteins at Various $\mathrm{pH}$

Figure 2 below shows that the highest protein solubility of CPI and SPI at various $\mathrm{pH}$ is at 8 , which means that the $\mathrm{pH}$ of the protein can be dissolved as much as on $\mathrm{pH}$ above or below the isoelectric point, the protein is changed so that the charge affinity between the protein molecules decreased. This causes the protein molecules readily biodegradable and will increase the solubility of the protein. Cowpea protein isolate have highly soluble at alkaline $\mathrm{pH}$ [17].

At $\mathrm{pH}$ above and below the isoelectric point, the protein will change the charge causes a decreased affinity between protein molecules, so the molecules are more easily broken down [18].

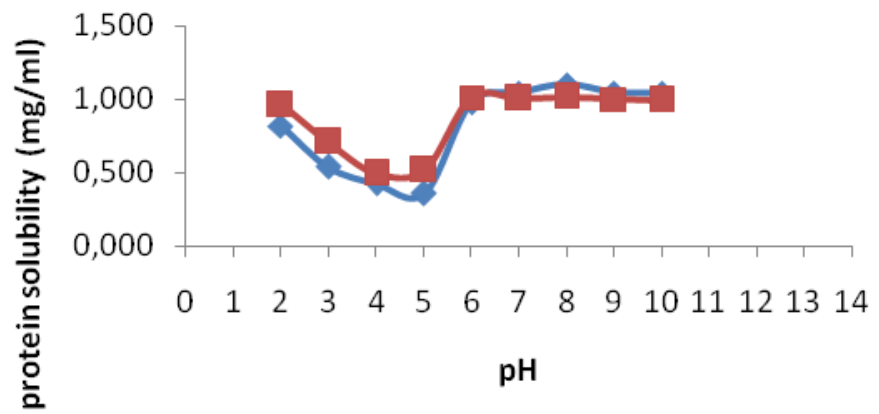

$\smile$ protein solubility of $\mathrm{CPI} \_$protein solubility of SPI

Fig 2. CPI and SPI protein solubility at various $\mathrm{pH}$

\section{2) Foam Capacity and Foam Stability}

Figure 3 below shows that the foam capacity of CPI is $68 \pm 4.00 \mathrm{ml} / \mathrm{g}$, while the foam capacity of SPI by $136 \pm 6.93$ $\mathrm{ml} / \mathrm{g}$. The low foam capacity of CPI influenced by the composition of protein isolate. SPI has a more complex composition fraction compared to CPI. It is thought bringing the fact to the foam capacity. One of the factors affecting the foam capacity that the protein composition [19]. The protein composition of CPI and SPI is different that it causes foam capacity different, too.

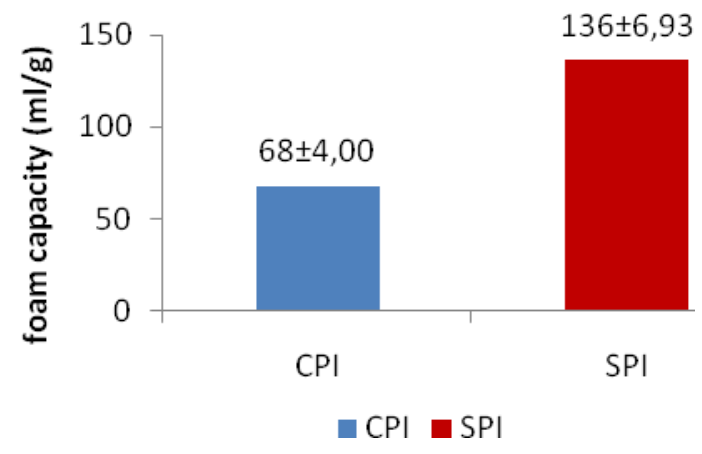

Fig 3. CPI and SPI foam capacity

Figure 4 below shows that the foam stability of CPI is $8 \pm 0.00 \%$ and the foam stability of SPI is $6 \pm 2.00 \%$. The high foam stability of CPI is influenced by the protein content. CPI has a higher protein content than the SPI so the foam stability more high. The foam stability is influenced by the protein content [18].

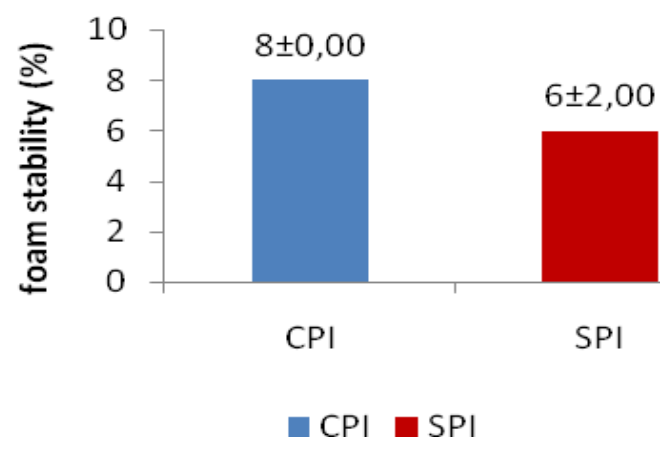

Fig 4. CPI and SPI foam stability 
3) Oil Holding Capacity (OHC)

Figure 5 below shows that the oil absorption of CPI is $84.89 \pm 1.36 \%$, while the oil absorption of SPI is $121.07 \pm 14.40 \%$. The low oil absorption of CPI affected particle size. SPI has a particle size smaller than CPI. The nature off at absorption is influenced by the size of the protein particles. The particle size and finer texture and uniform lead are more easily absorbed protein isolates and oil binding [15].

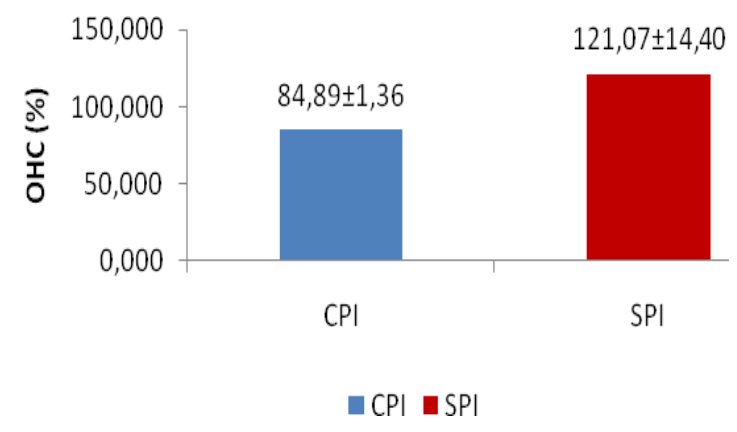

Fig 5. CPI and SPI oil holding capacity (OHC)

4) Water Holding Capacity (WHC)

Water Holding Capacity is as shown in Figure 6 below.

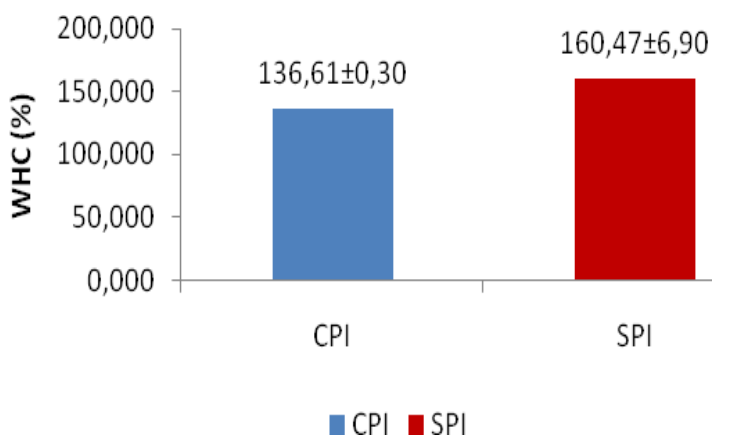

Fig 6. CPI and SPI water holding capacity (WHC)

This figure shows that the water absorption of CPI is $136.61 \pm 0.30 \%$ while the water absorption of SPI is $160.47 \pm 6.90 \%$. The low water absorption of CPI associated with 11S globulin fraction. 11S globulin fractions of CPI have less than the SPI so the water absorption of CPI is lower. The 11S globulin may improve the ability to bind water (WHC) [20]. Cowpea protein had lower hydrophobicity so the ability to bind water is lower [16].

\section{4) Emulsion Capacity and Emulsion Stability}

Figure 7 below shows that the emulsion capacity of CPI is $2.41 \pm 0.16 \mathrm{~m}^{2} / \mathrm{g}$ and emulsion capacity of SPI of $3.74 \pm 2.06$ $\mathrm{m}^{2} / \mathrm{g}$. Low emulsion capacity on CPI allegedly due to the composition of the different fractions of CPI and SPI. SPI has a composition of protein fractions that are more complex than CPI. One of the factors influencing the emulsion capacity is composition of proteins [19]. SPI has a composition more complex protein fraction so that emulsion capacity gets higher. Emulsion capacity influence the composition of proteins [17].

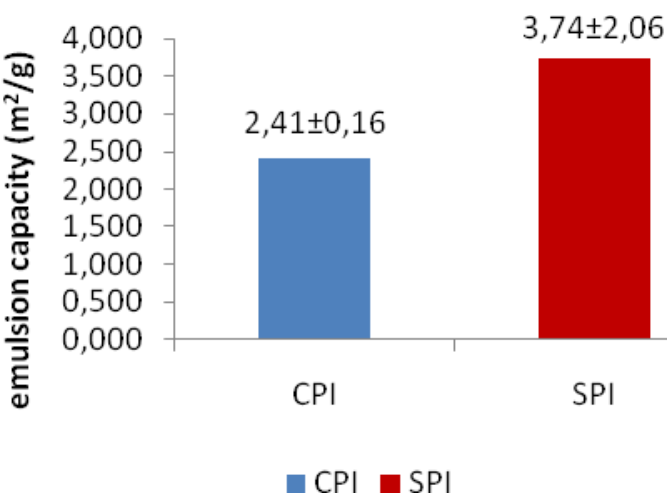

Fig 7. CPI and SPI emulsion capacity

Figure 8 below shows that the emulsion stability of CPI and SPI, respectively for $78.15 \pm 2.60$ hours and $72.74 \pm 4.15$ hours. Emulsion stability is related to the $7 \mathrm{~S}$ and $11 \mathrm{~S}$ globulins contained in CPI and SPI. CPI 7S globulin which has led to higher emulsion stability is also high. The $7 \mathrm{~S}$ protein fractions have better emulsion stability compared to11S protein fraction [10].

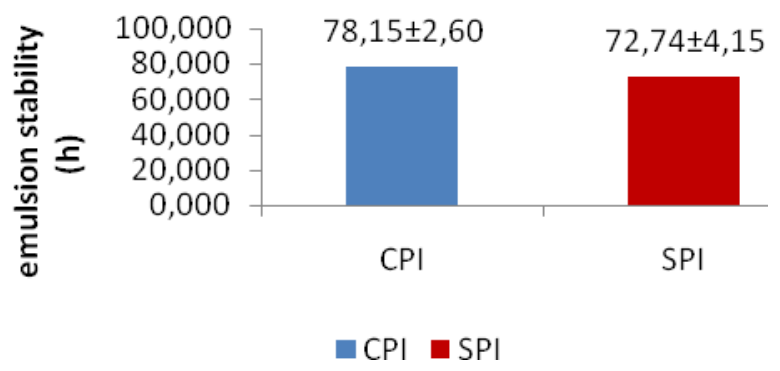

Fig 8. CPI and SPI emulsion stability

\section{5) Gelation}

Figure 9 (1) below shows the gelation of CPI is $4.00 \pm 0.00 \mathrm{gf}$ and the gelation of SPI is $5.00 \pm 0.00 \mathrm{gf}$. Figure 9 (2) shows the gelation of CPI and SPI after being stored in the refrigerator for 48 hours in a row amounted to $5.53 \pm 0.90$ and $7.87 \pm 0.58$ gf. This indicates that the gel formed from CPI softer than the SPI because the larger value indicated that the gel formed will be the hardest. Cooling treatment also increases the hardness of gel formed. Gelation properties of proteins often associated with the presence of $7 \mathrm{~S}$ and $11 \mathrm{~S}$ proteins. CPI $7 \mathrm{~S}$ globulin protein has greater than SPI, while SPI has $11 \mathrm{~S}$ globulin proteins larger than $\mathrm{CPI}$. The gel obtained from isolation glisinin (11S) gives the character a harder gel than gels obtained from $\beta$-conglisinin (7S), and the network structure is formed to have a difference between the two, depending of protein composition [21]. 


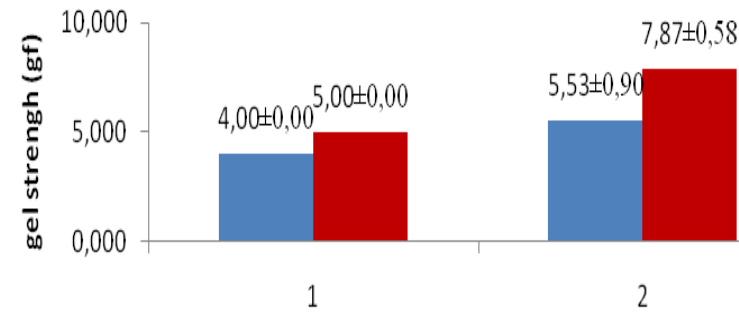

$\square C P|\square S P|$

Fig 9. (1) Gelation of CPI and SPI; (2) Gelation of CPI and SPI after being stored in the refrigerator about 48 hours

\section{CONCLUSIONS}

CPI has chemical properties including moisture content, ash content, carbohydrate content, protein content and fat content with value respectively $7.97 \%, 1.75 \%, 1.21 \%$, $88.06 \%$ and $1.05 \%$. More CPI containing $7 \mathrm{~S}$ globulin fraction compared with $11 \mathrm{~S}$. CPI has functional properties include solubility in a wide range of $\mathrm{pH}$ that dissolves at $\mathrm{pH}$ 8 , foam capacity and foam stability, respectively for $68 \mathrm{ml} / \mathrm{g}$ and $8 \%$, OHC and WHC with valuesrespectively $84.89 \%$ and $136.61 \%$, emulsion capacity and emulsion stability in a row by $2,41 \mathrm{~m}^{2} / \mathrm{g}$ and 78,15 hours, and gelation of $4 \mathrm{gf}$. CPI has a major fraction of protein band swith molecular weight of $59.11 \mathrm{kDa}$ and $54.22 \mathrm{kDa}$.

\section{NOMENCLATURE}

\section{Subscripts}

gf gramforce

\section{ACKNOWLEDGMENT}

We would like to thank to the Research and Community Service of Directorate General of High Education for financially supporting this research through Competitive Grant Research Program of Budget Year 2013.

\section{REFERENCES}

[1] Susilo, D. U. M. and Imelda, F. The manufacture of the cowpea cake (Vigna unguiculata) by mixing wheat flour. Script. Department Of Agricultural Technology. Pontianak State Polytechnic, 2013.

[2] Purwanti, S. Proposal of Cowpea. http://sripurwanti.blog.uns.ac.id /files/2010/02/proposal-kacangtunggak.pdf [accessed on 25 August 2013].

[3] Central Statistics Agency. 2013. Data Commodity Export Import of Soybean. http://www.bps.go.id/exim-frame.php?kat=2. [accessed on 21 May 2014].

[4] Triyono, A. Studies influence the addition of some acids on the process of protein isolation against of flour green bean protein isolates (Phaseolus radiatus L.) Chemical and Process Engineering Seminars. Subang: Grand Hall of Efficient Technology-Indonesia Science Institution, 2010.

[5] Suproborini, A. T. Optimization of Protein Isolate Making Process from Soybean (Glycine Max Merr) and Cowpea (Vigna unguiculata) Tempeh. Script. Jember: Faculty of Agricultural Technology. University of Jember, 2011.

[6] AOAC. Official Methods of Analysis of the Association of Analytical Chemist. Washington DC: Association of Official Chemist,2005.

[7] Sudarmadji, S., B. Haryono, dan Suhardi. The Procedure of Analysis for Food and Agriculture. Yogyakarta: Liberty, 1997.

[8] Thanh, U. H. and K. Shibasaki. "Major protein of Soybean Seeds, A Straight Forward Fractination and Their Characterization". J. Agric. Food Chem, vol 24, pp. 1117-1119,1976.
[9] Bollag, D. M., Rozycki, M. D., and Edelstein, S. J. ProteinMethods. (Second edition). New York: Willey-Liss, 1996.

[10] Zayas, J.F. Functionality of Protein in Food. Berlin: Springer, 1997.

[11] Parkington, J. K., Xiong, Y. L., Blanchard, S. P., Xiong, S., Wang, B., Srinivan, S., \& Froning G. W. "Food Chemistry and Technology: Chemical and Functional Properties of Oxidatively Modified Beef Heard Surimi Stored at $2^{\circ}$ C'. FoodSci. vol 65(3), pp. 428-433, 2000.

[12] Dias, A. R. G., Zavareze, E. R., Moacir, C. E., Elizabete, H., Debora, O. S. and Cesar F. C. "Pasting, expansion and textural properties of fermented cassava starch oxidised with sodium hypochloride". Carbohydrate Polymers. vol 84, pp. 268-275, 2011.

[13] Danuwarsa. "Proximate and fatty acids analysis on some commodities of beans". Bulletin of Agricultural Engineering. vol 11(1), pp. 5-8, 2006.

[14] Subagio, A., Windrati, W. S., dan Yuli, W. "Effects of Addition of Protein Isolates from Jack Bean Seed (Canavalia ensiformis L.) on The Characteristics of Cake". Journal of Techno and Food Industry. vol 14(2), pp. 136-143, 2003.

[15] Iskandar, A. Studies influence the addition of soy protein isolates as an binder materials againts the physical ad organoleptik quality of Meat Loaf. Script. Bogor: Faculty of Agricultural Technology. IPB, 2003.

[16] Horax, R., Hettiarachchy, N. S., Chen, P. and Jalaluddin, M. "Preparation and Characterization of Protein Isolate from Cowpea (Vigna unguiculata (L.) Walp)". Journal of Food Science. vol 69(2), pp. 114-118, 2004.

[17] Ragap, D. D. M., Babiker, E. E., and Eltinay, A. H. "Fraction, Solubility and Functional Properties of Cowpea (Vigna unguiculata) Protein as Affected by $\mathrm{pH}$ and/or Salt Concentration". J. Food Chemistry. vol 84, pp. 207-212, 2004.

[18] Aluko, R. E. And Yada, R. Y. "Structure-Function Relationship of Cowpea (Vigna unguiculata) Globulin Isolate: Influence of $\mathrm{pH}$ and $\mathrm{NaCl}$ on Physico-chemical and Functional Properties". Food Chem. vol. 53, pp. 259-265, 1995.

[19] Alleoni, A. C. C. And A. J. Antunes. Albumen foam stability and sovalbumin contents in eggs coated with whey protein concentrate. Rev. Bras. Cienc. Avic. Vol 6. No.2. Campinas/Revista Brasileira de Ciencia, 2004.

[20] Yuwono, S.S., Hayati, K. K., dan Siti, N. W. "Characteristic of physical, chemical and faction protein $7 \mathrm{~s}$ and $11 \mathrm{~s}$ ten varieties soybean production of Indonesia". Journal of Agricultural Technology. vol 4(1), pp. 84-90, 2004.

[21] Corredig, M. Protein-protein Interaction in Food di dalam Gaonkar AG dan McPherson A (ed). 2006. Ingredient Interactions; Effect on Food Quality 2nd Edition. London: CRC Taylor \& Fr ancis, 2006. 